\title{
The Challenge of Postsecularism
}

\section{Stanislaw Obirek}

University of Warsaw

\section{Abstract}

Since September 11 attacks on World Trade Center, the word "postsecularism" became a kind of key to explain the existing tension between the secular and "indifferent toward religion" Western world, and the growing religious fundamentalism. However, the existence of conflict between secular and religious worldviews and the attempts to overcome it are not new. The aim of my paper is to present a few examples of successful endeavors of worldviews exchanges between believers and nonbelievers. But, first, a definition of postsecularism will be suggested together with some critical reflection on the concept of religion. I will also discuss some inspiring ideas and theories of postsecularism from the last decade. I would like to suggest a comprehension of postsecularism as a kind of pluralism.

\section{Keywords}

postsecularism; Catholicism; religion; fundamentalism; belief; disbelief; paradigm

\section{Introduction}

I believe that it is important to situate the reality of postsecularism in the context of the vivid debate which is taking place in Europe and in the United States since the beginning of the 21st century. In this debate, representatives of different Humanities are involved among which I would like to mention some philosophers of religion (Leszek Kołakowski, Jurgen Habermas, Charles Taylor), political scientists (Olivier Roy, Kristina Stoeckl), sociologists (Zygmunt Bauman, Ulrich Beck), sociologists of religion (Peter L. Berger, Michele Dillon), theologians (Joseph Ratzinger, Jorge M. Bergoglio), and cultural anthropologists (Hent de Vries, Tomoko Mazuzawa). It seems to me that with the introduction of the concept of postsecularism by Jurgen Habermas, we gain a new analytical tool to interpret the present human condition. As we will see, the traditional categories such as secularization and desecularization, privatization and deprivatization, return of religion or politicization of religion are not anymore adequate to describe the new position of religion in public sphere and its relation to secular reality. In a certain

* Stanislaw Obirek, American Studies Center, University of Warsaw, Al. Niepodległości 22, 02653 Warsaw, Poland; s.obirek@uw.edu.pl 
sense, with the acceptance of the concept of postsecularism, it is possible to speak about a change of paradigm in religious studies in the sense given to this term by Thomas Kuhn in his classical study The Structure of Scientific Revolution: "To be accepted as a paradigm, a theory must seem better than its competitors" (Kuhn, 1970, p. 17).

I would like to start with a concise definition proposed by Kristina Stoeckl, the director of the Postsecular Conflicts Project at Innsbruck University, which I have found, on the one hand persuasive, and on the other hand open for further clarifications. It is worthy to note that in this new, postsecular context religion is not the same as it was before. As stated by Stoeckl: "Religion in post-secular society is not the same as the one in presecular society. The return of religion is not a falling-back into something that was there before. When we think about the post- as parable, we see that the religion that is presumably 'returning' has meanwhile changed as well" (Stoeckl, 2011, p. 2). Also, the relationship between religion and secularism has changed: "The co-existence of religious and secular worldviews, of religious and secular outlooks on society and politics, of religious and secular modes of understanding one's individual life create tensions. Postsecularity is a condition of permanent tension" (Stoeckl, 2011, p. 4). In other words, we need a different look at religion but also a different evaluation of secularity. For this reason, I would like to emphasize the complexity of the new approach to the concept of religion in the recent religious studies. A special place should be reserved for the sociologist of religion, James Beckford, who in 2012 gave a concise panorama of the different usages of the concept of postsecularism. Beckford named two Catholic theologians who in 1966 (Andrew Greeley) and 1982 (Richard John Neuhaus) mentioned postsecularism as a way to describe the situation of Christianity in the United States. As he observed, the usage of "postsecular" has become more varied and complex in the 21st century. Beckford grouped all the variety of usages of "postsecular" into six clusters: (1) Secularization, Deniers, and Doubters; (2) Building on the Secular; (3) Reenchantement of Culture; (4) Public, Resurgence of Religion; (5) Politics, Philosophy, and Theology; and (6) A Plague on All Your Houses. At the beginning of his article, the author clearly states that "The conclusion will be that the notion of postsecularity is problematic in itself and that it offers no help in explaining some important features of public religions in Britain" (Beckford, 2012, p. 1). At the end of his article, he gives a very critical conclusion: "My own skepticism about concepts of the postsecular stems from their failure to throw light on some of the most pressing issues concerning religion in public life today" (Beckford, 2012, p. 12). I have to admit that the critical evaluation of the concept of postsecularism made by Beckford might 


\section{Stanislaw Obirek The Challenge of Postsecularism}

be convincing; nevertheless, I will try to offer my own hypothesis, which is based mainly, although not only, on the Polish experience of dialogue between believers and nonbelievers.

\section{Ambiguity of the Concept of Religion}

One of the first theologians who realized that theological language is entangled in ideological implications (sociologists, of course, were aware of this fact earlier thanks to the contributions of Emil Durkheim and Max Weber) was Wilfred Cantwell Smith who suggested that, in order to understand better the religious phenomenon, it is necessary to abandon the concept of religion which was abused for ideological purposes (Smith, 1964, p. 48). Rejection of the concept of religion does not seem precise. I think that Smith meant the rejection of its false understanding. When Smith suggested this in the 1960s of the 20th century, his proposal was not only criticized but also misunderstood, or simply ignored. It seems to me, that Smith's proposal should be accepted not only as an intellectual provocation, which could give a more precise description of the religious dimension of human existence, but also as a real epistemological challenge. Smith's proposal can give religious persons more clarity about their religious identity.

Today it is more evident that each religion has an historical and evolutionary character, also religious pluralism seems self-evident and is increasingly accepted as a matter of fact also by adherents of different religions (in previous epoch religious pluralism was rejected). In this new context, the necessity to elaborate a new definition of religion seems obvious. It seems to me that the criticism of the way in which the concept of religion (and probably also the concept of God) was used and abused in Western theology is not only justified but also finds confirmation in books dealing with religion without God (Billington, 2002; Dworkin, 2013). In addition, the recent analysis of the secularization process has drawn attention to the phenomenon of essentialization of Christianity which, in effect, provoked Ivan Illich, to introduce the concept of, "corruption of Christianity," namely, the betrayal of its original legacy (Taylor, 2007, p. 737). It seems also that the discussion around the concept of religion is connected with the search for a new European identity: "What went on in the course of reshuffling the old categoriesseemingly a purely conceptual exercise-was in fact part of a much broader, fundamental transformation of European identity" (Masuzawa, 2005, p. XII). New anthropological perspectives demonstrate the impact of theological conceptions elaborated in relation with the concept of religion on the destructive development of human history. It is particularly evident in the 
relation between religious fundamentalism and violence. Hent de Vries stated in his book: "The way in which this 'transcendental historicity', as Husserl and Derrida would say, is overdetermined by 'religion', in all of its manifestations, forms the central concern of this book; the insight that this inflection betrays a certain 'violence' (to be defined) is its main thesis" (de Vries, 2002, p. XII). But perhaps the most important result of rejecting the concept of religion by Smith is a new methodology of religious studies. In this context, it is important to see the contribution of Wilfred Cantwell Smith to overcome this negative heritage of the concept of religion because it is a theoretical construction which does not correspond to the fullness and richness of religious experience. Theology, in fact, as an intellectual reflection on religious reality, it is part of this construction and has to be abandoned as well: "Theology is part of the traditions, is part of this world. Faith lies beyond theology, in the hearts of men. Truth lies beyond faith, in the heart of God" (Smith, 1964, p. 167). The conclusion to which Smith arrived is his appeal to reformulate also the traditional names of world religions: "On the verbal plane, I seriously suggest that terms such as Christianity, Buddhism, and the like must be dropped, as clearly untenable once challenged" (Smith, 1964, p. 175). In this context, it is possible not only to discuss concrete religious traditions, but also to negotiate their intellectual quality. And it is exactly what postsecularism is suggesting. As an example of this negotiation, I see an interesting proposal elaborated by the German sociologist Ulrich Beck in his book A God of One's Own which is directed to secular and to religious people as well, including Christians. According to Beck's vision, the crucial criterion for a believer is not an external doctrine elaborated in the history of Christianity, but a personal and individual decision to choose one's God. Therefore, in his view "Christianity may have undergone a conversion from an intolerance prosecuted with fire and sword to the limited form of tolerance" (Beck, 2010, p. 99). It seems to me that exactly this "limited form of tolerance" is at stake when we discuss the concept of religion and its impact on human history. The awareness of mutual correlation between religion and culture on the one hand, and the dependence of both on life experience, on the other hand, could be a good departure point for the process of "conversion" of all the participants in the public debate. I believe that stronger awareness of the limitations of respective worldviews, as an essential element in what heretofore has been known as "religion," would be helpful not only in the accurate understanding of that concept, but also will create the possibility to enter into a creative dialogue between representatives of secular and religious worldviews. 


\section{The Temptation of Religious (or Secular) Fundamentalism}

The best documentation of religious fundamentalism is the monumental five-volume edition, edited by Martin E. Marty and R. Scott Appleby, The Fundamentalism Project. This edition contains essays of many experts in religious studies from all over the world (Scott, 1991-1995). A quick overview of the contents of this voluminous documentation shows that no religion is exempt from the temptation of fundamentalism. A more disturbing portrait of religion, namely the close relationship between radical religion and violence, emerges from the many case studies that were presented in two recent publications by Mark Juergenmeyer and Jeffrey Kaplan. Juergenmeyer sees the connection between nationalism and religion a kind of new cold war (Juergenmeyer, 1993); Jeffrey Kaplan analyzes and shows the violent face of new radical and usually right-oriented movements like Christian Identity churches and different examples of radical religions in America (Kaplan, 2016).

I would like to leave the question of violence aside and reflect on a different and less known aspect of religious fundamentalism which is not as dangerous as the cases analyzed by the aforementioned scholars: the tendency of conservative theologians to withdraw from the modern world, which is stigmatized as a civilization of death, and to create an alternative reality. This tendency has gained strength and popularity in recent years; thanks to the writings and activities of Rod Dreher, particularly his book The Benedict Option (Dreher, 2017). Dreher also tries to popularize his ideas in his regular blog in "The American Conservative" and in articles in liberal media like "The New York Times."

A good illustration of his ideas can be found in his article "What Must Survive a Corrupt Catholic Church," published in The New York Times (Dreher, 2018). It is a good illustration of Dreher's conservative ideology. First of all, he mentions why he converted to Catholicism as a young man: "When I converted to Catholicism in my 20s, I seized my faith like a sword to be wielded against the world and the church's enemies. Arrogant, proud, triumphalist - that was the kind of Catholic I was as a young man. That was not the church's fault: It was mine. And then it was all taken away from me" (Dreher, 2018). I would say that it is a typical story of a young American conservative. Now, when he lost his confidence in the Catholic Church, he converted again, this time into Orthodoxy: "I left Catholicism for Eastern Orthodoxy, not because I expected to find a church free from sin, but because for various theological reasons, I thought it—not Protestantism-was the only way out. I needed valid sacraments, and I needed them in a church where 
I would not be overcome by fear and rage. In Orthodoxy, God gave me the graces of healing" (Dreher, 2018). Again, I would say, this is a typical path for someone looking for firm and certain ground.

But what was more important than his personal way of practicing Christianity in the Orthodox Church was a strong and judgmental attitude toward those who did not share his way of life. Even more, Dreher and his followers present an alternative civilization — the Benedict option—which means "by making monasteries, of a sort, of our homes and hearts, we may develop the spiritual disciplines necessary to endure this seemingly endless trial and to keep the light of faith burning brightly amid this new Dark Age" (Dreher, 2018). I do not think that this is a realistic proposal for our time. I think that a good alternative could be found in the postsecular worldview that is already practiced by some religious and secular people.

\section{Postsecularism avant la letter}

Before giving a few examples of how postsecularism is understood by some representatives of this theory, let me share with you my own experience of "permanent tension" between religious and secular worldviews. It was in the year 2000 when, as the editor of quarterly "Spiritual Life" [Życie duchowe] I invited some believers and some nonbelievers to answer a questionnaire concerning their respective worldviews. It was my pleasant surprise that many of them not only answered but were also grateful for being asked. Finally, the answers were published in the anthology What connects us? Conversations with non-believers. At the end of this experiment, I asked also Leszek Kołakowski to write the introduction. He agreed and entitled his interesting essay "Belief is valid, and disbelief is valid." As far as I know, this essay was not translated into English, so let me quote from it some passages. It seems to me that they illustrate perfectly what it today considered as a postsecular worldview. Kołakowski described the essays contained in the book What connects us? as follows: "it is a confrontation between faith and non-faith, a confrontation that is not only civilized, but is overall permeated with an intelligent desire to understand the other side" (Kołakowski, 2002, p. 13). Kołakowski stated not only that belief is valid and disbelief is valid but also underlined that both are necessary to culture. And what is even more important is that the existing and creative tension between these two positions is vitally needed for the development of our culture. Kołakowski indicated also the sources of the validity of disbelief: "The validity of disbelief is supported daily by hatred and arrogance of those believers who are called out to hatred and arrogance by bad priests" (Kołakowski, 2002, p. 13). I would like to mention a few 
names of agnostics' answers in my questionnaire: the sociologist Zygmunt Bauman about whom I will say more later, the lawyer Ewa Łętowska, the sociologist Świda-Ziemba, the philosopher Jan Woleński, the literary critic Michał Głowiński, and the writer Stanisław Lem. And a few names of believers: the philosopher Elżbieta Wolicka, the publicist Jan Turnau, the sociologist Ireneusz Krzymiński, and the theologian Wacław Hryniewicz. Some, as Jerzy Prokopiuk, described themselves as gnostics. All of them are public intellectualists with recognized academic achievements.

For me personally, the experience of collecting and editing different voices became the stimulus, to write a text in which Bauman's writings were set alongside John Paul II writings. I would like to refer to a fragment of this text, which seems to match with the postsecular context. Namely, the comparison of what seems to be incomparable "One, as the Pope, in 2003 published an apostolic exhortation called Ecclesia in Europa, the other in 2005 a book: Europe. An unfinished adventure. Ecclesia in Europa is a kind of summary of John Paul II's concerns about Europe and its Christian legacy, Europe. An unfinished adventure is a witty reflection on the unpredictability of a continent, which for thousands of years stood for the world's development of civilization. One can certainly question the appropriateness of this juxtaposition. John Paul II's reflections emerge from a clearly delineated tradition of western Christianity, whereas Zygmunt Bauman's thoughts cannot be easily traced to any one source. One could even say, that it is a programmatic distaste for any certainties. The only thing that unites them is a concern for the poor. Is this little, or much? Naturally, Zygmunt Bauman has devoted his entire life to the possibility of conquering the aporia of social formations, finding an answer in socialist sensitivities, and since his early childhood Karol Wojtyła believed that religion is the most appropriate answer to the anxieties of the human heart. Gesturing towards a common denominator-sensitivity to poverty-I do not intend to suggest that the Pope is a socialist, or that Zygmunt Bauman is a religious thinker. But I do want to suggest that different points of departure do not need to mean an impossibility of meeting" (Obirek, 2007, p. 132). As we will see in the next part of my reflection, the similarities between Zygmunt Bauman and Jorge Bergoglio are even more striking.

\section{Postsecularism in Praxis}

A good example of the practical consequences of the acceptance of postsecular worldview is the meeting between Jürgen Habermas and Joseph Ratzinger in 2004 in Munich. It was an academic exchange of two German intellectuals who never met before and whose widely recognized academic achievements are related to completely different fields. Habermas is a well-known 
philosopher not interested in religion and Ratzinger is a very influential Catholic theologian known for his critical attitude toward modern culture. In this debate, the term post-secularism was introduced by Habermas (who followed the German sociologist Klaus Eder and his article from 2002) as a way to create a dialogical space for secular and religious positions. In his response, Ratzinger not only accepted the proposed term but perceived postsecularism as a chance to overcome the existing impasse between religious and secular worldviews and underlined the positive contribution of critical thinking for the purification of religious fanaticism. To illustrate this process of mutual learning, I would like to quote just two statements in which they both recognized the necessity to hear one another. Habermas stated: "In the postsecular society, there is an increasing consensus that certain phases of the 'modernization of the public consciousness' involve the assimilation and the reflexive transformation of both religious and secular mentalities. If both sides agree to understand the secularization of the society as a complementary process, then they will also have cognitive reasons to take seriously each other's contributions to controversial subjects in the public debate" (Habermas, 2006, pp. 46-47). Ratzinger in his lecture accepted Habermas' suggestion by saying: "With regard to the practical consequences, I am in broad agreement with Jurgen Habermas's remarks about a postsecular society, about the willingness to learn from each other, and about self-limitation on both sides" (Habermas, 2006, p. 77).

A very similar approach to the mutual relation between religious and the secular dimension of our reality and with a practical application of postsecular thinking is present in Ulrich Beck's book with the interesting subtitle "Religion's capacity for Peace and Potential for Violence," which was already mentioned earlier. It is worth to mention that Beck as Habermas was not particularly interested in religious questions. Only in this book, published in 2008 in German and in 2010 in English translation, Beck decided to cope with religion as an important element of public sphere, and he wrote: "The secular society must become post-secular, i.e. skeptical and open-minded towards the voices of religion. Permitting religious language to enter the public sphere should be regarded as enrichment, not as an intrusion. Such a change is no less ambitious than the general toleration of secular nihilism by the religions" (Beck, 2010, p. 156).

My final example is the last book by Zygmunt Bauman Retrotopia which could be seen as his intellectual legacy. In the final chapter entitled "Epilogue: Looking Forward, for a Change," he made an enthusiastic reference to Pope Francis texts and gestures. Specifying a number of problems which humanity 


\section{Stanislaw Obirek The Challenge of Postsecularism}

has to cope with in the present moment of its history, Bauman finds one person who is able to supply an adequate answer: "I found in an address Pope Francis-currently the person among public figures of considerable great planet-wide authority who is bold and determined enough to raise and tackle this sort of questions" (Bauman, 2017, p. 138). Bauman quotes extensively a speech given by Pope Francis on the 6th of May 2016 when he received the European Charlemagne Prize. For Bauman, the Pope's speech is inspiring because he sees in it a concrete suggestion to resolve some problems of our world. For Bauman “The intention behind Pope Francis' message is to bring the fate of peaceful cohabitation, solidarity and collaborations of humans from the fuzzy and obscure realm of high politics" (Bauman, 2017, p. 139). And for this reason, Bauman concluded his book with a positive note: "The chances of fruitful dialogue, as Pope Francis remind us, depend on our reciprocal respect and assumed, granted and mutually recognized status equality" (Bauman, 2017, p. 140). The postsecular understanding of religious and secular mutuality is exactly about this.

Bauman's appreciation for Pope Francis could be confirmed by the sociologist Michele Dillon in the book Postsecular Catholicism: Relevance and Renewal in which the author stated that: "The Catholic Church has many resources that well match the postsecular turn" (Dillon, 2018, p. 165). Dillon made reference to Habermas' concept of "contrite modernity," which she applied also to the Catholic Church. And in the light of the recent statements made by Pope Francis in the context of clergy sex abuse in Pennsylvania, we can see that the "contrite Catholicism" might be real: "With shame and repentance, we acknowledge as an ecclesial community that we were not where we should have been... realizing the magnitude and the gravity of the damage done to so many lives." At the end of the letter, Francis says "it is essential that we, as a Church, be able to acknowledge and condemn, with sorrow and shame, the atrocities perpetrated by consecrated persons, clerics, and all those entrusted with the mission of watching over and caring for those most vulnerable" (Francis, 2018, Letter, 20 08). It will be interesting to comment some of the words of Francis from his trip to Ireland (August 25-26, 2018), but this I will leave for discussion. As Dillon writes: "A contrite modernity, just as contrite heart, does not give to despair over past failings. Rather, it has the values and cultural resources to amend its shortcoming, and to steer society back on track so that it can better realize its potential" (Dillon, 2018, pp. 2-3). 


\section{Postsecular Pluralism}

It is an open question if postsecularism could constitute a change of paradigm (Charles Taylor expressed his skepticism when I asked him what he thinks about this). We are still at the beginning of the debate. But I hope that I suggested some examples of constructive application of postsecular way of thinking in which religious and secular values are perceived not as opposed to each other but as complementary perspective.

A similar approach (although without mentioning postsecularism) was offered by the late Peter Berger in his last book The Many Altars of Modernity. Toward a Paradigm for Religion in a Pluralist Age, published in 2014. In this book, Berger used the religious pluralism of the modern world as a hermeneutical key for interpreting religious changes in the 21st century.

Let me end with one more passage from Bauman's Retrotopia: "We need to brace ourselves for a long period marked by more questions than answers and more problems than solutions, as well as for acting in the shadow of finely balanced chances of success and defeat. But in this one case, in opposition to the cases to which Margaret Thatcher used to impute it, the verdict "there is no alternative" will hold fast with no likelihood of appeal. More than at any other time we-human inhabitants of the Earth - are in the either/or situation: joining either hands, or common graves" (Bauman, 2017, p. 140). I would like to conclude with a personal note. Reflecting and coauthoring with Zygmunt Bauman's two books on our own respective life's experience, I discovered that believing in God or a lack of this kind of experience is of a secondary relevance. It is clearly stated in our first book Of God and Man (Bauman, 2015). This discovery was so exciting for both of us that we decided to follow our reflections and research in the second volume On the World and Ourselves dedicated to the epistemological consequences of this new approach to life (Bauman, 2015). Unfortunately, I cannot ask the coauthor of these two books if he agrees with me (Bauman died in 2017), but I see in them a good illustration of postsecular way of thinking.

\section{References}

Bauman, Zygmunt, and Obirek, Stanislaw. 2015. Of God and Man. Cambridge: Polity.

Bauman, Zygmunt, and Obirek, Stanislaw. 2015. On the World and Ourselves. Cambridge: Polity.

Bauman, Zygmunt. 2017. Retrotopia. Cambridge: Polity Press.

Beck, Ulrich. 2010. A God of One's Own: Religion's Capacity for Peace and Potential for Violence. Cambridge: Polity Press. 


\section{Stanislaw Obirek The Challenge of Postsecularism}

Beckford, James A. 2012. Public Religions and the Postsecular: Critical Reflection. Journal for Scientific Study of Religion, 1.

Berger, Peter. 2014. The Many Altars of Modernity. Toward a Paradigm for Religion in a Pluralist Age, Berlin: De Gruyter.

Billington, Ray. 2002. Religion Without God. London: Routledge.

Co nas taczy? Dialog z niewierzacymi [What connects us? Conversations with non-believers]. 2002. Kraków: Wydawnictwo WAM.

De Vries, Hent. 2002. Religion and Violence. Philosophical Perspectives from Kant to Derrida. Baltimore: Johns Hopkins University Press.

Dillon, Michele. 2018. Postsecular Catholicism: Relevance and Renewal. New York: Oxford University Press.

Dreher, Rod. 2017. The Benedict Option: A Strategy for Christians in a Post-Christian Nation. New York: Sentinel.

Dreher, Rod. 2018. What Must Survive a Corrupt Catholic Church. New York Times, 15 August. https://www.nytimes.com/2018/08/15/opinion/catholic-church-sex-abuse-pennsylvania.html.

Dworkin, Ronald. 2013. Religion Without God. Cambridge: Harvard University Press.

Francis [Bergoglio Jorge Mario]. Letter of His Holiness Pope Francis to the People of God. http://w2.vatican.va/content/francesco/en/letters/2018/documents/papa-francesco_20180820_lettera-popolo-didio.html.

The Fundamentalism Project. 1991-1995. Edited by Martin E. Marty and R. Scott, vol. 1-5. Chicago: University of Chicago Press.

Habermas, Jürgen, and Ratzinger, Joseph. 2006. The Dialectics of Secularization: On Reason and Religion, San Francisco: Ignatius Press.

Juergenmeyer, Mark. 1993. The New Cold War? Religious Nationalism Confronts the Secular State. Berkeley CA: University of California Press.

Kaplan Jeffrey. 2016. Radical Religion and Violence. Theory and Case Studies. London and New York: Routledge.

Kołakowski, Leszek. 2002. Wiara dobra, niewiara dobra [Belief is valid and disbelief is valid]. In: Co nas taczy? Dialog z niewierzacymi, [What connects us? Conversations with non-believers]. Kraków: Wydawnictwo WAM.

Kuhn, Thomas. 1970. The Structure of Scientific Revolution. Chicago: University of Chicago Press.

Masuzawa, Tomoko. 2005. The Invention of World Religions. Or, How European Universalism Was Preserved in the Language of Pluralism. Chicago: University of Chicago Press.

Obirek, Stanislaw. 2007. Dwa oblicza proroctwa. Jan Paweł II i Zygmunt Bauman wobec Europy [Two faces of prophecy: Jan Paweł II and Zygmunt Bauman on Europe]. In: Dokad zmierza Europa, przywództwo, idee, wartosci [Where is Europe Headed? Leadership, Ideas, Values]. Edited by. Halina Taborska, Jan S. Wojciechowski. Pułtusk: Akademia Humanistyczna.

Smith, Wilfried Cantwell. 1964. The Meaning and End of Religion. New York: Mentor Book. 
Stoeckl, Kristina. 2011. Working paper "Defining the Postsecular.” In Document Collection of the Italian-Russian Workshop "Politics, Religion and Culture in Postsecular Society (Faenza, 13-14 May 2011)", PECOB_Portal of East Central and Balkan Europe. http:// www.pecob.eu/flex/cm/pages/ServeAttachment.php/L/EN/D/7\%252Fd\%252F1\%252FD. 1f1f8fddc2dd41df40ac/P/BLOB\%3AID\%3D3100.

Taylor, Charles. 2007. A Secular Age. Cambridge: The Belkamp Press of Harvard University Press. 